\title{
THE IDENTIFICATION OF FUNGAL SPECIES IN DEAD WOOD OF OAK
}

\author{
Jolanta Behnke-Borowczyk ${ }^{\bowtie}$, Daria Wołowska \\ Department of Forest Pathology, Poznań University of Life Sciences \\ Wojska Polskiego 71C, 60-625 Poznań, Poland
}

\begin{abstract}
Background. The wood of dead, dying and living trees is a very important element of the forest ecosystem. The existence of many species of fungi is closely related to the presence of dead wood in the stand. The fungi community is a group of different species occurring in a certain time and space. The species composition of such a community is not constant and changes with the passage of wood into successive stages of decay. The impact on the formation of the fungi communities has a primary species composition occurring on and in the wood. The first wood is populated by species capable of decomposing fresh wood, then penetrating the structure of wood already violated, and in the final stage, settling on wood that is heavily decayed.

The aim of this study was to evaluate the species composition of fungal communities on pedunculate oak $Q u$ ercus robur L. wood. The material was downloaded from the area of the Drawa National Park (from $15^{\circ} 45^{\text {' }}$ to $16^{\circ} 45^{\prime} \mathrm{E}$, from $53^{\circ} 00^{\prime}$ to $53^{\circ} 15^{\prime} \mathrm{N}$ ) and divided into three stages of wood decomposition.

Methods. The detection of fungi was done, using the method of molecular biology. The use of molecular methods was based on polymerase chain reaction (PCR), cloning and sequencing by method described by Method of Sanger. The resulting sequence was compared with the reference sequence from the NCBI database. Results. The species composition of communities differed between various stages of decomposition. The most numerous was represented by Ascomycota. When analyzing the first stage of decomposition, 25 clones were obtained which represented three taxa. In the second stage 32 clones were obtained which represented 5 taxa. In the case of the third stage of decomposition, a positive result was not achieved. The taxonomy common in and with the II degree of decomposition was Ophiostoma novo-ulmi. The differences in the species composition between the species that settle the individual decomposition levels indicate the succession of species during the decomposition of wood. Except for species associated with wood degradation, these observed species have no significance for forest management.
\end{abstract}

Keywords: fungal communities, wood decay, dead wood, oak, Drawa National Park

\section{INTRODUCTION}

Dead wood is an important element of the forest ecosystem. The presence of trees weakened, dying, dead or with dead parts of the crown is a habitat of many organisms, including fungi (Szwagrzyk, 2014; Wierzbicka and Prange, 2014). The fungi community is a group of different species occurring in a certain time and space. The species composition of such a community is not constant and changes with the passage of time and the passage of wood into successive stages of decay. Fungi have a decisive influence on

\footnotetext{
*The paper financed from the fund for young scientists of the Faculty of Forestry, Poznań University of Life Sciences.
} 
the decomposition of wood - they modify its chemical and physical properties (Ottosson et al., 2014). The moment when the fungus begins to develop in wood is difficult to grasp (Gutowski et al., 2004). Oak is resistant to infections with fungal pathogens and wood decay caused by them (Szczepkowski, 2010). The aim of the study was to determine the types of fungal species decomposing the oak, taking into account the differences in the three stages of wood distribution.

\section{MATERIAL AND METHODS}

100 -year-old dead wood samples of oak were collected in October 2014 in a non-protected area in the Drawa National Park (from $15^{\circ} 45^{\prime}$ to $16^{\circ} 45^{\prime} \mathrm{E}$, from $53^{\circ} 00^{\prime}$ to $\left.53^{\circ} 15^{\prime} \mathrm{N}\right)$. The samples were taken by a traditional method (by separating the wood fragment third degree decomposition), and also by making a drill using a Pressler bit (first and second-degree decomposition). The samples were then numbered, and their degree of decomposition was determined according to a 5-degree scale modelled on the Hunter scale (1990). In the first stage of decomposition, an intact piece of wood was chosen, in a natural or near-natural colour (1-3 years after the beginning of the decay), the second stage used another piece of wood (5-20 years from hardening), with a hard to soft texture $(30 \%$ of the wood showed signs of decomposition and decay) and with a fading colour. The third stage of decomposition (20-30 years after hardening) was characterised by soft and loose wood of a colour completely different from a natural one (more than $30 \%$ of wood exhibiting decomposition symptoms, with completely crumbling bark). The collected material was milled using a SPEXTM SamplePrepTM Freezer/MillTM cryogenic mill at the Institute of Dendrology of the Polish Academy of Sciences in Kórnik. Test DNA was extracted using the Plant Genomic DNA Purification (Thermo Scientific) kit - according to the enclosed instructions. ITS $1 / 2$ rDNA amplification was performed with fungi-specific primers: ITS1-F (5 'CTT GGT CAT TTA GAG GAA GTAA 3') (Gardes and Bruns, 1993) and ITS4 (5 'TCC TCT GCT TAT TGA TAT GC 3') (White et al., 1990) by PCR. The PCR reactive mixture $(25 \mu \mathrm{l})$ consisted of $12.5 \mu \mathrm{l}$ of 2xMixPCR (A \& A Biotechnology), $0.2 \mu \mathrm{M}$ of each primer, $1.5 \mu \mathrm{l}$ of purified and diluted environmental DNA and $10.6 \mu 1$ of water. The PCR reaction was performed under the following conditions: denaturation of $94^{\circ} \mathrm{C}$ for $10 \mathrm{~min}$, followed by 35 cycles of denaturation, annealing and elongation at $94^{\circ} \mathrm{C}$ for $30 \mathrm{~s}, 42^{\circ} \mathrm{C}$ for $1 \mathrm{~min}$ and $72^{\circ} \mathrm{C}$ for $2 \mathrm{~min}$, the final elongation at $72^{\circ} \mathrm{C}$ for $10 \mathrm{~min}$. The visualization of the $5 \mu \mathrm{l}$ amplification product was performed in a $1.0 \%$ agarose gel dyed with Midori Green Advance DNA (Genetics). The PCR products were purified using the MinElute $\mathrm{PCR} \mathrm{Pu}-$ rification Kit (Qiagen, Crawley, UK). Next, the cloning was performed using pGEM-T. Easy according to the enclosed manufacturer's instructions. Individual clones created libraries for each of the analysed samples. The preliminary selection of clones was carried out on X-gal. White colonies were then selected and placed in $150 \mu \mathrm{l}$ of $10 \mathrm{mM}$ Tris $\mathrm{pH} 8.0$, treated at $100^{\circ} \mathrm{C}$ for $10 \mathrm{~min}$ and then centrifuged. The resulting DNA was amplified by PCR using fungal-specific primers (ITS1-F and ITS4) according to the protocol described above. The product obtained was 450 $650 \mathrm{bp}$. In the next stage, a second selection was made using the restriction fragment length polymorphism (RFLP) method. Two restriction enzymes were used: $H h a \mathrm{I}$ and BsuRI. Digestion was carried out overnight at $37^{\circ} \mathrm{C}$. The visualization of the digestive effect was performed in 3.0\% agarose gel dyed with Midori Green Advance DNA (Genetics). Digitising patterns were compared with the size marker (GeneRuler 100bp DNA Ladder, Thermo Scientific) for each library. Strips less than $80 \mathrm{bp}$ were not considered in the analysis because of the fear that they might represent primer dimers. A group of clones with identical digestive patterns with two enzymes was defined as an operative taxonomic unit (OTU). It is assumed that clones that belong to one OTU in an individual library - represent the same taxon. Representative clones were purified and sequenced by the Sanger method in the DNA Research Centre (Poznań). Deleted ends have been deleted. Sequences were compared with reference sequences from the NCBI database using the BLAST algorithm.

\section{RESULTS}

The identification of organisms using molecular biology techniques was based on the similarity of the 
Behnke-Borowczyk, J., Wołowska, D. (2018). The identification of fungal species in dead wood of oak. Acta Sci. Pol. Silv. Colendar. Ratio Ind. Lignar., 17(1), 17-23. http://dx.doi.org/10.17306/J.AFW.2018.1.2

Table 1. Frequency of fungal species detected by molecular method in 1 st and 2nd degree of wood decomposition Tabela 1. Frekwencja gatunków grzybów zidentyfikowanych za pomocą metod molekularnych w I i II stopniu

\begin{tabular}{|c|c|c|c|c|}
\hline $\begin{array}{l}\text { Taxon } \\
\text { Takson }\end{array}$ & I & II & $\begin{array}{l}\text { Number of sequence } \\
\text { NCBI database } \\
\text { Numer sekwencji } \\
\text { w bazie NCBI }\end{array}$ & $\begin{array}{c}\text { Similarity } \\
\text { Podobieństwo } \\
\%\end{array}$ \\
\hline Ascomycota sp. & & 15.1 & KJ508327 & 98 \\
\hline Aureobasidium pullulans (de Bary \& Löwenthal) G. Arnaud 1918 & & 2.7 & KM877470 & 99 \\
\hline Botryosphaeria stevensii Shoemaker 1964 & 52 & & AJ293881 & 100 \\
\hline Cadophora sp. & & 21.9 & DQ317330 & 97 \\
\hline Candida nitratophila (Shifrine \& Phaff) S.A. Mey. \& Yarrow 1978 & & 4 & JX965188 & 99 \\
\hline Nectriaceae sp. & & 4 & JN604455 & 99 \\
\hline Ophiostoma novo-ulmi subsp. novo-ulmi Brasier 1991 & 28 & 31.5 & KF854009 & 98 \\
\hline Tulasnella albida Bourdot \& Galzin 1928 & 20 & & AY373294 & 100 \\
\hline $\begin{array}{l}\text { No sequence in the database } \\
\text { Brak sekwencji w bazie danych }\end{array}$ & & 20.8 & & \\
\hline
\end{tabular}

test sequence to the reference sequence that is contained in the NCBI database (http://www.ncbi.nlm. nih.gov/date during search 15.04.205). In the tested samples fungi were found from the Ascomycota and Basidiomycota groups (Table 1). In the first stage of decomposition, which included 25 clones, two types of fungi belonging to the Ascomycota group were detected. These were: Botryosphaeria stevensii (52\% frequency), Ophiostoma novo-ulmi subsp. novo-ulmi (28\% frequency). One type was also identified from the Basidiomycetes group: Tulasnella albida $(20 \%$ incidence; Table 1). In the second stage of decomposition, which included 73 clones, fungi belonging to the Ascomycota group were represented by 6 taxa (frequency of $15.1 \%$ ), whose type could not be identified. In addition, the presence was established, of Aureobasidium pullulans (frequency of $2.7 \%$ ), Cadophora $\mathrm{sp}$. (Turnout 27.9\%), Candida nitratophila (4\% frequency), Ophiostoma novo-ulmi subsp. novo-ulmi (31.5\% frequency) and Nectriaceae sp. (4\% frequency; Table $1)$. In the case of tests relating to the third stage decomposition, it was not possible to amplify the PCR product. The species common to the first and second stages of decomposition was Ophiostoma novo-ulmi subsp. novo-ulmi (Table 1).

\section{DISCUSSION AND CONCLUSIONS}

Dead wood is a living environment of many living organisms. Some species of fungi occur on specific tree species (Kwaśna et al., 2016). It was shown that the second degree of decomposition of wood was represented by a significantly more numerous group of taxa. In the fungal group of the second stage of decomposition 73 clones were found, while in the first, 25 clones. Eight taxons of fungi were found that lived in oak wood. According to Fukasawa et al. (2009), the succession of dead wood is primarily related to the density of populated wood (and other physicochemical factors), the enzymatic properties of microorganisms, ecological specialisation, and water and nitrogen content.

In the research community of fungi in the first and second stages of decomposition was saprotrophs and weak parasites has been confirmed, including the fungi Ophiostoma, Cadophora and those from the Nectriaceae family. Previous studies indicate that in the early stages of fungal colonisation, the organisms belonging to the Basidiomycota, and over time they in turn, are dominated by fungi belonging to the Ascomycota (Fukasawa et al., 2009; Kim et al., 2009; Lumley et al., 
2001). The results of this study, as well as the results obtained by Kwaśna et al. (2016) indicate that Ascomycota dominates in the first and second decomposition of wood. In the community of fungi predominated Ascomycota, constituting $81-89 \%$ of breeding fungi. This is in line with the general preferences of Ascomycota for deciduous wood (Gutowski et al., 2004). Ascomycota participate in the process of decomposition of wood, resulting in rotting (Schwarze, 2007). They also participate in the forest litter decomposition process (Osono and Takeda, 2006). Recived of differences in the community of fungi in the first and second stages of decomposition was created from succession resulting from fungal inter- and interspecies competition (Gutowski et al., 2014). The presence of the pathogen Ophiostoma novo-ulmi subsp. novo-ulmi was found in both the first and second stages of wood degradation. It is an aggressive breed of fungi O. ulmi, which causes dutch elm disease. This pathogen is associated with the elm trees in the wood: the specimen of Scolytus scolytus Rtzb. and the multicellular S. multistriatus Marsh (Mańka, 2005; Oszako, 1997). Ophiostoma species are found on oaks, but they are not considered to be directly responsible for their decay. $O$. querci is described as appearing on the oak stem joint (Münch) (Kaus and al., 1996; Przybył, 1995). Kwaśna and others (2016) also identified fungi belonging to the genus Ophiostoma, including $O$. canum (Münch) Syd. \& P. Syd, on oak dead wood originating from the Drawa National Park.

In the first stage of decomposition, numerous fungi from the Ascomycota Botryosphaeria stevensii group were identified. This species is responsible for the development of cancer and oak dying (Alves et al., 2004). Their presence in the first stage of decomposing wood may be associated with a deterioration in the health of the trees during their lifetime. One species of fungus belonging to the Basidiomycota Group - Tulasnella albida, which causes decay of wood in both deciduous and coniferous species, was also identified in the first decomposition stage. Its occurrence was found among others. during research conducted in the Ukraine (Ordynets, 2012).

In the fungal communities occupying the dead oak wood, the second degree of decomposition indicated more than $15 \%$ of the taxa belonging to the Ascomycota. Unfortunately, neither the genus nor species could be identified. In addition, in the above distribution, as many as $10.9 \%$ of the organisms were not identified at all because of the lack of deposited sequences in the database used. In a group of fungi, occupying oak wood in the second stage of decomposition, a species of Aureobasidium pullulans was identified. Studies conducted in Europe and North America, found that this species inhabited timber amongst others (Schoeman and Dickinson, 1997). Aureobasidium pullulans was identified on coniferous oak dating back to the 1980's (Przybył, 1995). Classical methods of identifying microorganisms based on morphotyping, used by Kwaśna et al. (2016) in studies that also included oak wood in different degrees of decomposition, which came from the Drawa National Park did not confirm the presence of this organism. In the second stage of decomposition of oak wood, more than $20 \%$ of $\mathrm{Ca}$ dophora fungi were found causing the rotting of soft wood. Species belonging to this genre occupy the polar regions and are found on elements of wooden structures (Blanchette, 1991). Several species belonging to the genus Cadophora have been identified on material derived from wooden huts (C. malorum, C. luteo-olivacea, $C$. fastigiata). Most of the trials that identified these species, were in contact with the ground or were underground (Blanchette et al., 2004), which may be significant in the case of the forest-dwelling process of fungi belonging to this type. The wood collected for the study came from both standing and lying trees. Fungi found in the soil could easily deal with this new niche in the further phases of degraded timber. There was only a $4 \%$ incidence of $C$. nitratophila found in the fungi community in the second stage of oak wood decomposition. This fungus does not matter in the process of decomposition of wood, which occurs in the forest environment. This species was used during the reduction process of methyl, amongst others in the production of nitrate reductase (Boyer, 1976). The presence of Candida species in oak originating from the same area of the Drawa National Park is also confirmed by Kwaśna et al. (2016). Also, the presence of Nectriaceae fungi was detected in the second wood decomposition. Fungi belonging to this type may be pathogenic or saprotrophic (Mihál, 2011). Second decomposition wood originating from the Drawa NP provided a favourable environment for the existence of these organisms. 
Tests undertaken in the third decomposition stage, could not amplify the PCR product. This may indicate that the DNA was very low or the DNA of fungi was in poor condition. The study did not show the presence of species causing characteristic oak rot. Not all identified taxa are directly related to plant tissue decomposition processes. Using the molecular method, less taxa were identified than using classical microorganism identification techniques (Kwaśna et al., 2016). Classical identification methods (Kwaśna et al., 2016) have also shown presence in the tested samples of fungi from the Basidiomycota. However, the independent classical method of identifying microorganisms has proved to be similar to self-contained molecular methods, not fully effective in identifying fungi from this group. The use of molecular techniques is justified especially in the case of organisms that do not produce good and easy to identify fruiting bodies. Most of the studies use both methods, but one of them usually dominates (Hilszczańska, 2004). Hence, for the full imaging of the fungi community in dead oak trees from Drawa National Park, the results of the analysis of the fungi community made by both methods should be used, which appears to be complementary. Molecular analysis is a costly technique, which is one of its major drawbacks. In addition, the close kinship of the species may result in misidentification, due to the similarity within the ITS region. It is also worth noting that some taxons will not be found in the database and we will not be able to match RFLP patterns, which will not allow us to assign results to a higher taxonomic rank, such as the cluster (Hilszczańska, 2004). In addition, a portion of the DNA sequence deposited is misidentified (Bridge et al., 2003).

The differences in species composition between communities occupying individual decomposition stages may indicate the succession of species during the decomposition of wood. Some species of fungi can be present at any stage of wood decay, others are associated with a particular stage. In addition to the species responsible for the wood degradation processes, other species were found in the trials, often of little significance to forest management.

\section{REFERENCES}

Alves, A., Correia, A., Luque, J., Phillips, A. (2004). Botryosphaeria corticola, sp. nov. on Quercus species, with notes and description of Botryosphaeria stevensii and its anamorph, Diploida mutila. Mycologia, 96(3), 598-613.

Blanchette, R. A., Jurgens, J. A., Held, B. W., Arenz, B. E., Smith, J. A. (1991). Decay of historic and archaeological wooden structures: degradation processes and molecular characterization of wood destroying fungi (pp. 5108-6030). St. Paul. USA: University of Minnesota.

Blanchette, R. A., Held, B. W., Jurgens, J. A., McNew, D. L., Harrington, T. C., Duncan, S. M., Farrell, R. L. (2004). Wood-destroying soft rot fungi in the historic expedition huts of Antarctica. Appl. Environ. Microbiol., 70(3), 1328-1335.

Boyer, P. D. (1976). The enzymes. Vol. 13: Oxidationreduction. Part C: Dehydrogenases (II), oxidases (II), hydrogen peroxide cleavage (pp. 275-279). Lincoln: Academic Press.

Bridge, P. D., Roberts, P. J., Spooner, B. M., Panchal, G. (2003). On the unreliability of Publisher DNA sequences. New Phytolog., 160, 43-48.

Fukasawa, Y., Osono, T., Takeda, H. (2009). Microfungus communities of Japanese beech logs at different stages of decay in a cool temperate deciduous forest. Can. J. For. Res., 39, 1606-1614.

Gardes, M., Bruns, T. D. (1993). ITS primers with enhanced specificity for basidiomycetes - application to the identification of mycorrhizae and rusts. Molec. Ecol., 2, 113-118.

Gutowski, J. M. (red.), Bobiec, A., Pawlaczyk, P., Zub, K. (2004). Drugie życie drzewa [The afterlife of a tree]. Warszawa-Hajnówka: WWF, Poland [in Polish].

Haze M. (Ed., 2012). Forest protection manual. Vol. 1. Appendix to the Order no. 57 of the Director General of the State Forests dated 22 November 2011. Warsaw: State Forests Information Centre.

Hilszczańska, D. (2004). Metody identyfikacji ektomikoryz [Methods of ectomycorrhizal identification]. Leśn. Pr. Bad., 4, 161-168 [in Polish].

http://www.ncbi.nlm.mih.gov/

Hunter, M. L. Jr. (1990). Wildlife, forests and forestry: Principles of managing forests for biological diversity. Englewood Cliffs, New Jersey: Prentice-Hall.

Kaus, A., Schmitt, V., Simon, A., Wild, A. (1996). Microscopical and mycological investigations on wood of pedunculate oak (Quercus robur L.) relative to the occurrence of oak decline. J. Plant Physiol., 148, 302-308. 
Kim, G.-H., Lim, Y. W., Choi, Y.-S., Kim, M.-J., Kim, J.-J. (2009). Primary and secondary decay fungi on exposed pine tree logs in the forest. Holzforschung, 63, 633-638.

Kwaśna, H., Mazur, A., Łabędzki, A., Kuźmiński, R., Łakomy, P. (2016). Communities of fungi in decomposed wood of oak and pine. For. Res. Pap., 77(3), 261275. http://dx.doi.org/10.1515/frp-2016-0028

Lumley, T. C., Gignac, L. D., Currah, R. S. (2001). Microscopic communities of white spruce and trembling aspen logs at different stages of decay in disturbed and undisturbed sites in the boreal mixed-wood region of Alberta. Can. J. Bot., 79, 76-92.

Mańka, K. (2005). Fitopatologia leśna [Forest phytopathology]. Warszawa: PWRiL [in Polish].

Mihál, I. (2011). Occurrence of fungi of the genus Nectria s. 1. (Ascomycota, Hypocreales, Bionectriaceae, Nectriaceae) in Slovakia. Folia Oecol., 38, 1, 80-88.

Ordynets, O. (2012). New records of corticioid fungi with heterobasidia from Ukraine. Turk. J. Bot., 36, 590-602.

Osono, T., Takeda, H. (2006). Fungal decomposition of Abies Needles and Betula leaf litter. Mycologia, 98(2), 172-179.

Oszako, T., (1997). Influence of water stress, defoliation and inoculation with Ophiostoma querci on pedunculate oak seedlings. Folia For. Pol. Ser. A, Forestry, 39, 5-15.

Ottosson, E., Nordén, J., Dahlberg, A., Edman, M., Jönsson, M., Larsson, K. H., ..., Ovaskainen, O. (2014). Species associations Turing the succession of wood-inhabiting fungal communities. Fungal Ecol., 11, 17-28. https:// doi.org/10.1016/j.funeco.2014.03.003

Przybył, K. (1995). Zamieranie dębów w Polsce. I. Objawy chorobowe i grzyby występujące na nadziemnych organach zamierających dębów Quercus robur L. oraz cechy orfologiczne grzybów Ophiostoma querci i $O$. piceae [Rooting of oaks in Poland. I. Disease symptoms and fungi occurring on the overgrown bodies of Quercus robur L. and the morphological characteristics of the fungi Ophiostoma querci and O. piceae]. Ecolog., Ideas, 8, 4, 78-83 [in Polish].

Schoeman, M., Dickinson, D. (1997). Growth of Aureobasidium pullulans on lignin break down products at weathered wood surfaces. Mycologist, 11(4), 168-172.

Schwarze, F. W. M. R. (2007). Wood decay under the microscope. Fung. Biol. Rev., 21, 133-170.

Szczepkowski, A. (2010). Resistance of pedunculate oak (Quercus robur L.), from trees of different health status, to decay caused by fungi. Forest Res. Works, 71(2), 125-133. https://doi.org/10.2478/v10111-010-0009-y

Szwagrzyk, J. (2014). Zamieranie i rozkład drzew jako procesy ekologiczne [Tree death and decasy as ecological processes]. Stud Mater. Centr. Eduk. Przyr.-Leśn. Rogów, 16(41/4), 9-14 [in Polish].

White, T. J., Bruns, T., Lee, S., Taylor, J. (1990). Amplification and direct sequencing of fungal ribosomal RNA genes for phylogenetics. In: T.J. White (Ed.), PCR Protocols: a guide to methods and applications (pp. 315322). New York, USA: Academic Press.

Wierzbicka, A., Prange, K. (2014). Martwe drewno - trudny temat. Jak uczyć o roli martwego drewna w lesie? [Dead wood - difficult issue. How to teach about role of dead wood in forest?]. Stud Mater. Centr. Eduk. Przyr.-Leśn. Rogów, 16(41/4), 16 (41/4), 380-386 [in Polish]. 


\title{
OKREŚLENIE BIORÓŻNORODNOŚCI GRZYBÓW W MARTWYM DREWNIE DĘBOWYM
}

\begin{abstract}
ABSTRAKT
Wstęp. Drewno martwych, zamierających oraz żywych drzew to bardzo ważny element ekosystemu leśnego. Istnienie wielu gatunków grzybów jest ściśle uzależnione od występowania martwego drewna w drzewostanie. Zbiorowisko grzybowe to grupa różnych gatunków występujących w określonym czasie i przestrzeni. Skład gatunkowy takiego zbiorowiska nie jest stały i zmienia się wraz z przechodzeniem drewna w kolejne stopnie rozkładu. Duży wpływ na kształtowanie się zbiorowisk grzybowych ma pierwotny skład gatunkowy występujący na i w drewnie. Jako pierwsze drewno zasiedlają gatunki mające zdolność rozkładu świeżego drewna, następnie wnikające w strukturę drewna już naruszonego, a w końcowym etapie gatunki zasiedlające drewno mocno rozłożone.

Celem pracy było określenie składu gatunkowego zbiorowiska grzybowego w drewnie dębu szypułkowego Quercus robur L. pochodzącego z terenu Drawieńskiego Parku Narodowego (od $15^{\circ} 45^{\prime}$ do $16^{\circ} 45^{\prime} \mathrm{E}$, od $53^{\circ} 00^{\prime}$ do $\left.53^{\circ} 15^{\prime} \mathrm{N}\right)$ w zależności od stopnia rozkładu drewna określanego według skali Huntera. Drewno w I stopniu rozkładu było zdrowe, o nienaruszonej strukturze, naturalnym kolorze i nietkniętej korze. W II stopniu rozkładu drewno było umiarkowanie miękkie, jego kolor zmienił się wyraźnie. Obserwowano mniejsze lub większe plamy lub zgniłe pierścienie, zwłaszcza w zewnętrznych warstwach, a kora częściowo odpadła. W III stopniu rozkładu drewno było miękkie, o zmienionym kolorze. Warstwy zewnętrzne drewna uległy rozpadowi, a kora była nieobecna.

Metody. Detekcję grzybów przeprowadzono metodą techniki biologii molekularnej opierającej się na reakcji łańcuchowej polimerazy (PCR), klonowaniu i sekwencjonowaniu metodą Sangera. Otrzymane sekwencje porównywano z sekwencją referencyjną z bazy danych NCBI.

Wyniki. Skład gatunkowy zbiorowisk różnił się między poszczególnymi stopniami rozkładu. Najliczniej była reprezentowana gromada Ascomycota. Analizując pierwszy stopień rozkładu, otrzymano 25 klonów, które reprezentowały trzy taksony. W drugim stopniu otrzymano 32 klony, które reprezentowały pięć taksonów. W III stopniu rozkładu nie udało się uzyskać wyniku pozytywnego. Taksonem wspólnym w I i II stopniu rozkładu był Ophiostoma novo-ulmi. Różnice w składzie gatunkowym pomiędzy zbiorowiskami zasiedlającymi poszczególne stopnie rozkładu świadczą o sukcesji gatunków w trakcie rozkładu drewna. Poza gatunkami związanymi z degradacją drewna zaobserwowano gatunki bez znaczenia dla gospodarki leśnej.
\end{abstract}

Słowa kluczowe: zbiorowiska grzybowe, rozkład drewna, martwe drewno, dąb, Drawieński Park Narodowy 